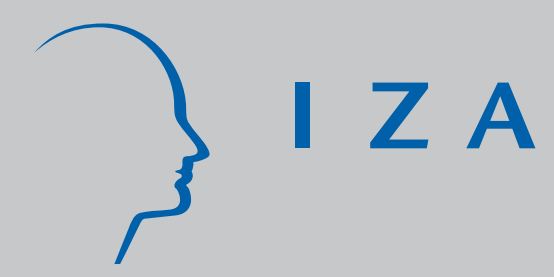

IZA DP No. 866

Immigrant Adjustment in France and Impacts on the Natives

Amelie Constant

August 2003 


\title{
Immigrant Adjustment in France and Impacts on the Natives
}

\author{
Amelie Constant \\ University of Pennsylvania \\ and IZA Bonn
}

\author{
Discussion Paper No. 866 \\ August 2003
}

\author{
IZA \\ P.O. Box 7240 \\ D-53072 Bonn \\ Germany \\ Tel.: +49-228-3894-0 \\ Fax: +49-228-3894-210 \\ Email: iza@iza.org
}

This Discussion Paper is issued within the framework of IZA's research area Mobility and Flexibility of Labor. Any opinions expressed here are those of the author(s) and not those of the institute. Research disseminated by IZA may include views on policy, but the institute itself takes no institutional policy positions.

The Institute for the Study of Labor (IZA) in Bonn is a local and virtual international research center and a place of communication between science, politics and business. IZA is an independent, nonprofit limited liability company (Gesellschaft mit beschränkter Haftung) supported by Deutsche Post World Net. The center is associated with the University of Bonn and offers a stimulating research environment through its research networks, research support, and visitors and doctoral programs. IZA engages in (i) original and internationally competitive research in all fields of labor economics, (ii) development of policy concepts, and (iii) dissemination of research results and concepts to the interested public. The current research program deals with (1) mobility and flexibility of labor, (2) internationalization of labor markets, (3) welfare state and labor market, (4) labor markets in transition countries, (5) the future of labor, (6) evaluation of labor market policies and projects and (7) general labor economics.

IZA Discussion Papers often represent preliminary work and are circulated to encourage discussion. Citation of such a paper should account for its provisional character. A revised version may be available on the IZA website (www.iza.org) or directly from the author. 
IZA Discussion Paper No. 866

August 2003

\section{ABSTRACT \\ Immigrant Adjustment in France and Impacts on the Natives}

The purpose of this paper is to study the immigrant performance in France and the impacts on the natives by drawing on research findings from the existing academic literature on the economics of French migration. The research questions are: how do immigrants fare with respect to wages, employment, and occupational choices; are immigrants in competition with the natives, and do they harm or improve the labour market situation of natives; does the presence of immigrants alter the internal migration flows of natives; and what is the role of the business cycle and natives' sentiments on the immigrant flows? The studies reviewed showed that while some immigrant groups are faring well, assimilation and intergenerational mobility has not taken place to a full extent. Overall, immigrants hardly affect the wages and employment levels of natives, and there are no significant displacement effects. However, the social and cultural distance between immigrants and natives is crucial in natives' sentiments. Moreover, business cycles and labour market conditions play a significant role on migration. In France of 2000, there remains a significant gap between policy goals and outcomes, indicating that integration through cultural and political venues alone is not enough but should be combined with a systematic treatment of the needs of the labour market. Lastly, there is substantial need for further studies on immigrants in France.

JEL Classification: F22, J18, J24, J31, J61, J62

Keywords: $\quad$ international migration, public policy, human capital, occupational choice, earnings assimilation, immigrant workers, intergenerational mobility, impact on natives, business cycle, native sentiments, France

Amelie Constant

Population Studies Center

University of Pennsylvania

3718 Locust Walk

Philadelphia, PA 19104-6298

Email: aconstan@pop.upenn.edu 


\section{Introduction}

The study of migration has garnered increased attention by political advocates and social scientists as immigration is heavily debated in the political arena. In an era of increasing globalisation of economies migration has also become an integral part of international economics, and remains of the outmost concern among all countries that face immigration challenges. In Europe, the immigrant population has reached an all time high competing with the so-called traditional immigrant countries such as the US, Canada, and Australia. In France - a longstanding country of immigration - every statistic shows that immigration will keep increasing. Given the recent incidents in France, migrants without documents occupying churches (les sans-papiers), the deportation and expulsion of illegal workers, ${ }^{1}$ the popularity of the extreme right in the local and national elections, the heightened anti-migration sentiments ${ }^{2}$ and complaints that discrimination against immigrants is on the rise, migration management appears to have become rather complex and has polarised debates on migration.

The latest French census of 1999 enumerated 4.31 million legal immigrants, who make up $7.4 \%$ of the French metropolitan population, and 3 million of whom are of North African decent. In Paris, the capital of France, already one person in six is an immigrant. Whereas these statistics are often perceived as high, they are still below or comparable to the immigration figures in other European countries like Germany and the UK. Further, while it is unquestionable

\footnotetext{
${ }^{1}$ Nicolas Sarkozy, the Minister of Interior, has recently reinstituted a policy of group deportations by plane, which was abandoned several years ago under pressure from human rights groups. A new law approved by the government in April 2003 will toughen conditions for entry and residence in France and create a fingerprint database of visa applicants.

${ }^{2}$ Le Pen's National Front campaign both in 1997 and 2002 accused Arabs and Africans to be responsible for France's high unemployment and crime, and classified them as a threat to French bloodlines.
} 
that a large part of the foreign population in France has ties to the former French colonies, in the new century, the demographic picture of France shows that it has a large immigrant population with increasingly diverse ethnic profiles.

Officially, France refuses to recognise ethnic communities and insists that immigrants must fully embrace the French culture so that the Republican ideals and model be sustained. In France, ethnic identity was always viewed as an obstacle to national solidarity and to immigrant integration. The country's migration policy has always been to integrate foreigners into the nation by putting into practice the Enlightenment ${ }^{3}$ and the Republican ideals as derived from the Revolution ${ }^{4}$. The Republican assimilation model aspires to efface ethnic and national origins in the second generation, so that immigrant children can hardly be distinguished from French children. The Republican ideal was strengthened by the relatively relaxed citizenship laws and the integrating institutions such as schools, the military, unions, the French communist party, and the Catholic Church. It aimed at inculcating both French and immigrant children a common civic culture and the pride of French values. In reality, however, the French assimilationist concept of citizenship and French identity often clashes with the "ethnic minority" claims.

Driven by the notion of the unified French culture, integration measures have always played a crucial part in French migration policy. Hence, one would expect that integration into the French society should be much more advanced and successful than in other European countries. However, for the last 30 years the particular needs of the French labour market have

\footnotetext{
${ }^{3}$ Enlightenment denotes the liberal thought of Voltaire and Diderot, and emphasises reason, toleration and natural law, plus a confidence in modern man and his achievements. Above all they promoted the idea of change and progress as good things.

${ }^{4}$ The notion that all individuals are treated equally regardless of birth, class, race, or religion.
} 
not been met. Whereas some immigrant groups manage to perform well, It is not surprising that migrants often fail on the labour market and this is the basis for economic, social, and political tensions and disintegration in this unofficially multi-cultural society. A successful economic integration into the native labour market is a necessary, although not sufficient condition for the functioning integration of immigrants into society. As long as immigrants perform well in economic terms, for instance they remain employed, earn a decent salary, and provide goods and services that are in demand, they can be integrated without having to resemble the natives. At the same time, the adaptation of the national culture may also help foster assimilation into the labour market.

Since France tightened its immigration law in 1974, almost all non-European immigration is due to family reunification, albeit clandestine migration and refugees are also of the essence. Family linked migration continues to predominate immigrant flows, since no sufficient attempts have been made to develop a migration policy that directly accounts for economic motives. In reality, the integration of family-related migration has not been accomplished. Moreover, the integration of the second generation migrants has not been as successful due to the inability of the education system to include, guide, and prepare them for the demands of the labour market in the new century.

The purpose of this chapter is to study the immigrant adjustment and its impacts on the natives from an economic viewpoint by drawing on research findings from the existing academic literature on French migration. Surprisingly and in spite of the great importance the issue of migration has for the French economy, there have only been very few studies by economists dealing with this topic. In this chapter, I will review a very small but growing body of research 
on immigrants in France, to assess the immigrants labour market accessibility, their economic assimilation, their intergenerational progress, and impact on natives.

The research questions of this chapter will, therefore, be fourfold: First, how do the various groups of immigrants fare on the French labour market? Namely, how do they perform in terms of wages, unemployment, occupational choices, and self-employment? Are they performing similar to equally educated natives, is there a longer-term adjustment process, and any prospect of convergence to natives' position in the labour market? Second, are immigrants in competition with natives, and do they harm or improve the labour market situation of natives? Do they take jobs away by competing with natives, or do they create jobs for the natives, as entrepreneurs or due to the fact that their employment ensures demand for native employment due to complementarities, or alternatively, do they operate in different markets and they never interact with natives? And, do immigrants cause a reduction or an increase in the income levels of the natives? Third, does the presence of immigrants alter the internal migration flows of the natives? That is, do natives move away from the areas with a high concentration of immigrants, are they drawn into these areas, or are they migrating irrespective of the immigrant flows? Fourth, I will appraise the question on the sentiments of natives vis-à-vis the immigrants and investigate the role of the business cycle on the immigrant flows.

The outline of the chapter is as follows: First, I will present an overview of the socioeconomic characteristics of the immigrant population in France, and second I will delineate the main phases of the immigration system in the post-war period and outline how the various immigration policies affected the quantity and "quality" of immigrants. In the forth and fifth sections I will review and evaluate the findings of the existing scientific literature on the 
economic assimilation and intergenerational mobility of immigrants, and the immigrant impact on natives as well as the natives attitudes towards immigrants, and the role of the business cycle, respectively. Finally, I will draw my concluding remarks.

\section{Current Statistics on the Immigrant Population}

In this section, I will reveal major facts about the immigrant population in France. The emphasis is on presenting and describing the major characteristics of the migrants and their children as they pertain to the labour market and their social environment. The summarised characteristics are based on the 1999 census, and are compared with previous censuses to identify and depict the long-term developments of the immigrant groups in France.

According to the definition adopted by the High Council for Integration in 1991 (Haut Conseil de l'Intégration, $\mathrm{HCI}$ ), an immigrant is a foreign born person who entered the French territory under a foreign nationality, lives in France at least for one year, and has not acquired the French citizenship. Immigrants who have naturalised or the children of immigrants who are born in France are considered French citizens. However, a question on the country of origin has always been included in the census, and the French government knows, at least since 1962, how many foreigners have naturalised, or how many French are not born with a French nationality. There are three categories in the census questionnaire: French by Birth, French by naturalisation, and foreigner. Since the 1999 census, the French Statistical Office (Institut National des Statistiques et Études Économiques, INSEE), has established some clarifying statistical definitions between a foreigner and an immigrant. Accordingly, a foreigner is a person who declared a different than French citizenship, and an immigrant is a person born abroad who is a 
foreign national or has acquired the French citizenship. Both categories have in common the group of individuals who are born abroad and have foreign nationality (SOPEMI 2001, p. 82).

Currently, similar to the US and the UK, France defines citizenship by the jus soli principle according to which immigrants who are born in the country are automatically granted citizenship. In addition, the children of immigrants who grow up in France are automatically French citizens at the age of 18 . The so-called second migration immigrants, thus, disappear easily from immigration records. Consequently, immigration statistics for countries like France and the UK might present lower numbers of foreigners than actual.

Table 1 depicts the distinction between foreigners and immigrants by place of birth and nationality. Clearly, the definition of foreigners is based on the nationality, while the definition of immigrants on the place of birth. Table 1 reveals this by stating that $100 \%$ of all immigrants have been born abroad, while in 1999 only $84.4 \%$ of the foreigners were not born in France. Among the total population, $10 \%$ of the people have been born abroad. In international comparisons in Europe, the key measure is not the share of foreign born but the "share of immigrants in total population". For France in 1999, this number (not included in Table 1) has been $7.4 \%$. The foreigners, on the other hand, have been $5.6 \%$ of the population. Moreover, Table 1 states that from all of those who have been French at birth $2.9 \%$ were born abroad. Only $34 \%$ of the naturalised citizens but $94.4 \%$ of all French citizens have been born in France.

TABLE 1 ABOUT HERE 
Out of the 4.31 million legal immigrants enumerated in the 1999 census, immigrant men constitute $9.5 \%$ and immigrant women $7.7 \%$ of the respective male and female populations. In reference to the "active" population ${ }^{5}$ or the population in the labour force immigrants occupy an 8.6\%. Figure 1 exhibits the stock of foreigners as enumerated over the last 3 censuses. This figure shows how the origin mix has changed over the years, and the largest group dominating the stock of foreigners, comes from sub-Saharan Africa. While in 1982 Algerians were the leading country of origin, both in the 1990 and 1999 censuses the largest group were Portuguese, followed by Moroccans, Algerians, and Turks. Moreover, the stock of the European Union foreign population, e.g. from Portugal, Italy and Spain, has been declining, and the presence of people from other non-EU countries has been increasing.

\section{FIGURE 1 ABOUT HERE}

Figure 2 shows the inflow of the foreigners as per cent of total inflow into France from EU and from the major sending countries outside the EU over the last decade. Where data was available this figure depicts the annual inflows in 1990 and 1999, as well as the annual average inflows between 1990 and 1998. The numbers demonstrate the great gamut of foreign nationalities that is part of the French immigration experience. This figure also suggests that with the exception of the EU countries migration to France remains unabashed. Morocco, Algeria and Turkey remain the major sending countries while the inflow from the EU countries has substantially decreased over the last decade. In fact, Moroccans account for the largest part of

\footnotetext{
${ }^{5}$ The active population in France comprises all persons who have a job, or who are looking for a job, as well as those in the military.
} 
inflows because they are mainly seasonal workers, employed in agriculture, but also employed in tourism and the catering business.

\section{FIGURE 2 ABOUT HERE}

Compared to the 1990 census, the immigrant population in France of 1999 has increased by $3.4 \%$ but this increase is similar to the increase of the entire population. In general, since 1975, the immigrant population in France is rather stable. Although the number of immigrants from EU countries is 9\% lower than in 1990, the number of immigrants from non EU countries is $38 \%$ higher. Specifically, the number of immigrants from the Sub-Saharan Africa is up by $43 \%$ compared to the 1990 statistics, and Turks constitute more than $2 \%$ of the immigrant population. With regards to the age distribution, the immigrant population in France of 1999 is getting somewhat older. Only $8 \%$ of the immigrants are less than 20 years old, while one fifth of them are older than 60. Finally, the 1999 census shows that men and women immigrants are almost equally represented (Glaude and Borrel 2002).

The immigrant statistics of the 1999 census also show a feminisation of the immigrant workers, when compared to the sex composition of the immigrant workers in previous censuses. For example, whereas in 1982 only $22.3 \%$ of the immigrant workers were women, in 1990 the female share had been risen to $27.6 \%$, and by 1999 it has reached $35.3 \%$. However, this is not surprising, given that the only venue of immigration to France is family reunion. The recent prominent presence of women migrants has also contributed to the overall increase in the labour force participation (LFP) of immigrants, while the participation rate of immigrant men has slightly decreased. Although immigrant women have tried to close the gap in LFP they are still 
less represented in the labour market and their LFP rates vary by nationality. Among the 15-64 year old immigrant women, only $57 \%$ are active in the labour market, a percentage below the average of $63 \%$ for all women. Immigrant women from Portugal and south-east Asia, namely Vietnam, Cambodia, and Laos, have the highest labour force participation while Turkish women have the lowest. In sharp contrast, immigrant men's LFP is higher than the LFP of all men (78.6\% against $74.9 \%$ respectively, see Glaude and Borrel 2002).

In spite of the higher LFP, immigrant workers have been, and still are, concentrated in the lower rungs of the socioeconomic ladder. They comprise $18 \%$ of the non skilled blue collar workers and $6 \%$ of the employees without an education degree. Overall, $53 \%$ of immigrant men and $20 \%$ of immigrant women are manual workers, and tend to concentrate in labour-intensive and low-skilled industries. Immigrants are usually working under temporary contracts and often in part-time or dead-end jobs. While men are frequently in the construction, automobile or other heavy industry women are in domestic services, hotels, and restaurants. Over the years immigrants have remained in these jobs and a quarter of a century later, their children are also in these same jobs. It is clear that, contrary to popular beliefs, immigrants are not intruding on the jobs held by natives. They rather occupy jobs that are shunned by natives.

Along with their occupational segregation goes their geographic concentration. Immigrants are geographically concentrated in some areas of the country, usually in the poorer suburbs of big urban centres or "banlieux." More than a third lives in the Ile-de-France region. On average, between 1993 and 1999, 40.5\% of the Portuguese, 29.9\% of the Maghrebiens, and 40.7\% of the Africans lived in the greater Paris area. Besides the Parisian area, immigrant prominence is found in the South-West and South-East French cities. Interestingly enough, the 
geographic concentration of immigrants does not necessarily imply a mingling among the various immigrant groups. Each immigrant group tends to stay among the same nationals. That is, the Spaniards mostly reside in the south of France, the Italians are in the Alpes and Jura areas, the Maghrebians along the axis of Phone-Saone, and the Turks in the East close to the GermanSuisse borders (Jayet et al. 2001). Moreover, even within the immigrant localities the different nationalities remain distinctly apart. There is, for example, the "Maghrebian" neighbourhood, the "Jewish" neighbourhood, the "black-A frican" neighbourhood, etc.

In general, unemployment and dire macroeconomic conditions affect workers adversely. In France, as in other immigrant countries, the immigrant population is more vulnerable to economic crises and more likely to be affected by unemployment. As declared by the 1999 census, the unemployment rate for immigrants is almost twice as high as that for natives $(22 \%$ versus $13 \%$ respectively). This is higher by $18 \%$ than the unemployment rate in the 1990 census. However, unemployment rates vary by gender and nationality. Within the immigrant population, women are affected by unemployment the most with $25 \%$ of women being unemployed versus only $20 \%$ of men. Among all immigrant groups, Portuguese are the least affected by unemployment. Statistics also show that those naturalised immigrants are less affected by unemployment, compared to those who did not naturalise.

Another difficulty that immigrants in France face is job accessibility. In the 1990s, job perspectives for those entering the labour market have become worse, and are disproportionately tough for the younger immigrant workers. Not only immigrant youth faces the highest unemployment rates but once they are in unemployment the probability to return to employment is much lower compared to natives. Moreover, even when immigrants have a job, their 
remuneration is much lower than that of the national average. On average, immigrant men earn $90 \%$ less than the average salaries of all men. Immigrant women earn, on average, $76 \%$ less than the average salaries of all women in part-time employment.

Because of the tight employment market, many immigrants in France choose to naturalise so they can have access to better jobs. According to the 1999 census, more than a third of the immigrant population in France acquired the French nationality, a number higher by 19\% since the last census in 1990. Still, this is a low rate of naturalization compared to the US or Canada. Almost $50 \%$ of the immigrants from south-east Asia, Poland, Italy, and Spain have acquired the French citizenship. In contrast, only a very small percentage of the immigrants from Algeria, Morocco, Turkey, and Portugal have acquired the French citizenship. For the first time in 2000, the number of naturalisations crossed the symbolic number of 150,000 (Héran 2002). ${ }^{6}$

With the exception of European Union citizens, immigrants in France have no political rights, except the right to demonstrate and strike, and the freedom to create associations. On the other hand, immigrant workers in France have the same insurance benefits as the French (according to the social security code). Once matriculated in the French social security system, immigrants can receive health, disability, and life insurance, they can start accumulating pension rights, and can benefit from unemployment insurance similar to the French workers.

The 1992 Education Survey by INSEE showed that immigrant families had twice as many school age children as the rest of the families. However, this fact rather manifests the

\footnotetext{
${ }^{6}$ One of the requirement for French citizenship is to have resided at least for 5 years in France
} 
higher immigrant fertility of the 1970s. Immigrant fertility in the 1990s has somewhat declined as immigrants align their fertility with that of French natives the longer they stay in France (Héran 2002). However, immigrant children's education has not aligned with that of the French children. Immigrant children are under-represented in the general and technical education and over-represented in vocational education.

To complete the picture of the immigrant population in France I turn to their real estate behaviour. Owning a house manifests the permanency of immigrants as well as their perception of regarding France as "home." Out of the 1,370,000 immigrant households in France enumerated in $1999,30.7 \%$ own their own house and $64.7 \%$ are renting apartments. Among the renters, $31.5 \%$ live in HLM buildings, or low income - low rent housing, or workers' low-rise dwellings. Immigrant home ownership is still low, though, compared to about $60 \%$ by the French. Overall, while the immigrant population in France has been living in France for at least 20 years, this section has shown that the immigrants in France do not resemble the native population vis-à-vis raw socioeconomic statistics.

\section{The Immigration System in France Since Word War II}

Clearly, the choice of immigration policy regimes affects both the quality and quantity of the immigration flows, the performance of immigrants in the host country, as well as the way natives perceive immigrants. In this section I will delineate the major changes in the French immigration laws in chronological order as they took place after the Second World War and show how the changes in the immigration policy have affected the quantity and quality of the immigrants to France. 
France has always been an immigrant nation for both economic and demographic reasons. In the nineteenth and early twentieth centuries, when most European countries were exporting immigrants, France was importing immigrants, pursuing expansionary immigration policies. The distinctive property of the French immigration system is that France is open to receive immigrants from both its former colonies for demographic reasons (thus resembling the US, Canada, and Australia), and immigrants from the Mediterranean region for purely economic reasons (thus, resembling demand driven migration as implemented by Germany, for example).

Although heavy recruitment of immigrant workers occurred during World War II, it was only after the second war, when France needed additional workers to meet the needs of the labour market, that immigration became the government's priority. The ordinance of 1945 created the National Office of Immigration (ONI), a neutral government agency, which has all the power to control, regulate, oversee, carry through, and ensure the smooth recruitment of immigrants and their families. A similar ordinance guaranteed liberal access to French nationality. Belgium and Germany, along with Poland, Italy, and Spain were the first countries to supply immigrant manpower to France. Some 430,000 immigrants were imported during this first five-year economic plan.

In the 1950s and 1960s the French government encouraged immigration under a "laissezfaire" policy while upholding the nation's republican values. Immigration during this era was mainly due to decolonisation from Algeria and Indo-China, culminating to the Algerian independence in 1962. In 1962, for example, 350,000 Algerians, or "French Muslims" were enumerated in France. In parallel, during this period many foreign workers from Southern Europe also went to work in France. Whereas at times they entered without a work contract or 
outside the proper channels of the ONI they were able to regularise their status relatively easy once they were in France. Furthermore, until 1960 France was offering asylum to thousands of applicants who were welcomed to stay and were offered assistance for integration.

The years 1962-1965 after the Algerian independence were the troubled years of immigration in France. There was a rise in immigration from Spain, and a decline in immigration from Italy, while immigration from Portugal started emerging. During that same period, immigration from Algeria developed strongly, and immigration from Sub-Saharan Africa marked its debut in France (Tapinos 1975). Naturally, the mass migration to France during this era has created a shortage of housing. Thousands of immigrants lived together in overcrowded rooms often in run-down areas, in barrack-style housing, or self-built shacks and wooden settlements.

The year 1970 marked the beginning of the Turkish migration to France. Up to that time, France actively sought immigrant workers who were viewed as the cornerstone of economic recovery. However, emerging social conflicts coupled with the international economic crisis in the early 1970s, lead the French government to start imposing regulations on immigration. The Ministry of Interior and Labour took several measures that aimed at controlling and suspending migration. Combined with higher productivity standards by French firms, these measures were successful in reducing the number of immigrants entering France by $44 \%$ by $1972 .^{7}$ Still, in January 1973, the register of foreigners kept by the Ministry of the Interior, included: 789,000

\footnotetext{
${ }^{7}$ A process of economic restructuring has started in the 1970s. Manufacturing and manual work has fallen and salaried, office related employment has increased. This has affected the plight and economic position of immigrants in France trem endously.
} 
Algerians, 742,000 Portuguese, 573,000 Italians, 571,000 Spaniards, 218,000 Moroccans, and 119,000 Tunisians.

The general recession of 1973 had serious effects on many European economies as energy prices quadrupled. Following other neighbouring countries with immigration issues, in July 1974, the French right government of d'Estaing officially suspended all labour migration with the exception of EU nationals. ${ }^{8}$ Immediately, an upsurge of a diversified form of immigration took place, namely family reunification. The highest influx of immigrants occurred between the years 1962 and 1971 for men and between 1972 and 1981 for women. Overall, most of the immigrants in France today arrived between 1962 and 1974. By 1975, Algerians were representing the second largest group after the Portuguese.

The immigration halt of 1974 also caused the number of asylum seekers to skyrocket. As the number of asylum applications rose, so did the refusal rate, rising from $4 \%$ in 1976 to $85 \%$ in 1990. Still, in the 1970s, asylum applicants were allowed to work, and by 1981 - under the socialist Mitterand government - they enjoyed an automatic right to work. It was often the case that applicants who had found employment could be legalised and they could obtain further housing assistance and help with integration (Wihtol de Wenden 1994).

In the mid-1970s, the French government (reflecting rising social tensions and frictions) also introduced several additional legislative measures. These measures aimed, mainly, to curb illegal immigration and even included sanctions on employers who hired illegal immigrants. In

\footnotetext{
${ }^{8}$ However, the halt of recruitment exempted certain industries, such as construction and mining, and seasonal workers in agriculture.
} 
parallel, several measures were taken to induce return migration, although they were not successfully realised. Strict anti-immigrant legislation was later repealed and in 1978, the Conseil d'État cancelled these decrees so there are no more general restrictions for immigrants to enter France along with their families. However, family reunion, which has dominated the immigrant flows, has escalated the housing problems. Eventually, the government had to order additional reunification restrictive guidelines in order to alleviate the severity of housing issues.

In the 1980s, large immigrant populations settled in France in spite of the troubled French economy. Among them, political refugees and asylum seekers constituted the overwhelming majority. The socialist governments of the 1980 s tried to ease the restrictions on migration. Since the 1980s the census numbers of the new immigrants to France showed a rather stagnant immigrant population. However, this appearance could conceal the fact that many of the new entrants have acquired the French nationality, and have thus vanished from the immigration statistics. Since the 1982 census, it is also evident that the national origin mix of immigrants had changed. Whereas the principal continent of origin of immigrants to France was Africa, especially sub-Saharan Africa, there has been a considerable increase in the number of immigrants from Asia from $8 \%$ in 1982 , to $12.5 \%$ in 2000 . By the late 1980 s, the number of asylum seekers had declined, only to sharply rise again from the mid-1990s on.

In the early 1990 s there was a slight decline in migration, which can be related to the implementation of some very aggressive anti-immigrant legislation. ${ }^{9}$ In 1991, the automatic right

\footnotetext{
${ }^{9}$ French migration policy had been more sympathetic before: "La France ne peut pas accueillir toute
} la misère du monde, mais elle doit savoir en prendre fidèlement sa part." (Michel Rocard - former French Prime Minister - 1990). 
to work by asylees was abolished and employment authorisation depended on the needs of the labour market. Further, in July 1993, Charles Pasqua, the French Interior Minister, announced a zero migration policy, and introduced the infamous Pasqua laws. According to these laws the police became more powerful in checking identities and deporting legal immigrants, the jus soli principle was modified so that immigrant children born in France were not automatically French, immigration for family reunification became more difficult to be realised, an increased waiting period was introduced, foreign students were not allowed to work in France, and asylum seekers lost their chances to appeal asylum rejections.

In spite of the rise of the far-right Le Pen and the anti-immigrant agenda, during the mid to late 1990 s, about $12 \%$ of the new entrants in the labour market were immigrants, constituting about 100,000 entrants per year. The majority of the new immigrants in the 1990 s were from Africa (especially from Senegal and Mali), while the number of immigrants from the Maghreb ${ }^{10}$ countries had diminished. Still, the main reason for justifiable immigration in France was family reunification. However, clandestine migration was also of the essence.

Paradoxically, French unions have adopted nuanced policy preferences in the recent years, in spite of high unemployment levels. In the 1980s and 1990s, for example, unions have often opposed certain anti-immigration measures taken by various governments. Instead, they delved into organizing immigrant workers (Haus 1999). Assuming that the government cannot fully control migration flows, the unions' argument is that unorganised and irregular immigrant workers undercut unionised native workers.

\footnotetext{
${ }^{10}$ Officially, the Maghreb Countries are: Libya, Tunisia, Algeria, Morocco, and Mauretania. The word Maghreb is Arabic and means "western."
} 
Lastly, at the end of 1997, political refugees and asylum seekers represented about $4 \%$ of the total foreign population living in France, and they were of diverse nationalities coming from Asia, to Europe, to Africa. By 1999, asylum applications have increased again with Chinese nationals being the largest group of applicants. According to the Ministry of Foreign Affairs' Office for the Protection of Refugees and Stateless Persons (OFPRA), the volume of applications for asylum has increased by 272 per cent since 1996 and by 22 per cent compared to 2000 . However, the rate of admission remained relatively low at roughly 12.4 per cent in 2001. Main countries of origin were China (12.9\%), Turkey (9.1\%) and the Democratic Republic of Congo $(7.5 \%)$.

An integral part of France's immigration policy has been granting amnesties to illegal immigrant workers. ${ }^{11}$ Major amnesties occurred in 1968, 1974, 1981, and 1995. The amnesty of 1997 legalised about 87,000 illegal immigrants out of 150,000 applicants. The ratified new legislation and immigration law in 1998 , which modified for the $25^{\text {th }}$ time the 1945 ordinance, aimed to increase highly skilled immigration by giving scholars and scientists special immigrant status. The new law also extended the criteria for residence permits by emphasizing the rights of the person and the respect for family life, as well as it aimed to combat illegal immigration. Still, France lags behind the US and Germany in its pursuit for highly skilled labour while importance is still being given to family ties.

Up until the late 1990s, the French policy and public debate focussed on immigration per se and little thought was given - even less action was taken - to the implementation of an

${ }^{11}$ Illegal workers does not necessarily mean that they entered France illegally. The majority of them were entering legally under a tourist or student visa. 
effective integration. An affirmative action plan to battle discrimination against immigrants in the labour market was announced in 1998. The French government promised to: (1) end the practice of permitting employers to specify that they want French nationals when they request workers from a government employment office; and (2) re-examine current requirements that persons employed by state-run companies must be French nationals--one estimate is that 25 to 35 per cent of jobs in France require French citizenship (IGAS). In 2000, the Directorate of Population and Migrations adopted several regulations to facilitate the integration of foreigners. In particular, these regulations aimed at supporting young people having difficulty in entering employment, at implementing local contracts for reception and integration, and at introducing a single education support measure (SOPEMI 2001).

The booming period 1998-2000 of high employment has left the immigrant population in France untouched and marginalised. One of the reasons is that the labour market demand changed and required more qualified workers, who would speak the language fluently and possess more sophisticated skills. The emphasis was to employ individuals in strategic sectors such as information technology (IT), telecommunications, and health. French employers openly declared the need to recruit qualified workers and scientists from the non EU countries (Deneuve 2002). In 2000, the French authorities under pressure from the professional union of information technology issued about 1,600 residence permits to foreign qualified IT specialists. In 2001, they more than doubled the permits to 4,000. Amazingly, this new hiring under the so-called "scientific visa" had been carried through under the maximum discretion and had even escaped the press and the media. Alternatively, the decline in demand for unskilled labour since the 1970s is mainly due to the change in the industry composition of domestic demand for goods and services and not so much to the technical progress per se (Goux and Maurin 2000). 
In sum, over the last half century, France has received several waves of immigrants from diverse origins, and with distinctly different motives and aspirations. During the "thirty glorious years," until the official stop to recruitment in 1974, immigration was an encouraged and welcomed phenomenon. Since then, immigration has continued under a different label, and has been perceived on and off as detrimental to the economy and as a threat to the social norms. Immigrants in France have access only to jobs in the private sector. With the exception of university and research and development jobs, immigrants do not work in the public sector, and can hardly be found in the freelance professions such as lawyers and doctors. Nonetheless, immigration to France continues apace and French immigrants keep enduring transnational ties with their country of origin. The question to be answered in the next section is whether these immigrants and their children have successfully adjusted and assimilated in the French labour market.

\section{Integration and Labour Market Assimilation}

In this section I survey the existing research on the labour market assimilation of men and women immigrants in France, as well as that of their children. First, I look at the philosophical, political, sociological, and economic distinction between, assimilation, insertion, and integration.

\subsection{Definitions of Integration}

In economics, assimilation has the meaning of becoming similar in monetary and occupational terms. A popular definition for assimilation is then, the rate at which the earnings 
of immigrants converge to the earnings of comparable natives ${ }^{12}$ in a way that both groups are indistinguishable. Assimilation is a process of achieving similarity as immigrants are exposed into the host society's norms and rules and invest in human capital with additional years of residence in the host country. Similarly, occupational assimilation would mean that immigrants achieve to hold jobs of the same status and prestige as comparable natives. Besides wages and occupations, economic assimilation covers many other areas, such as unemployment, labor force participation, economic mobility, business ownership, etc.

In France, assimilation implies the idea "of unilatera $1^{13}$ adaptation of the immigrant to the laws and the customs of France, the superiority of French culture and national identity, and the requirement that the immigrant renounce his or her identity and culture" (Weil and Crowley 1994, p. 111). This was the official motto by which the immigration system was functioning - at least until the mid 1970s - and has effectively acculturated and absorbed many waves of immigrants into the famous "creuset français" or the French melting pot.

Insertion is a term that was introduced in the mid-1970s by the intellectuals "to designate the right to refuse assimilation, to defend and to preserve collective identity, and to refuse to adapt to dominant French culture" (Weil and Crowley 1994, p. 111). This term prevailed until 1984 and made people conscious of the right to be different. Later in the 1980s, the concept and parlance of integration became a priority in public discourse, and religion became particularly

\footnotetext{
${ }^{12}$ Alternatively, assimilation is defined as the rate at which the earnings of newly arrived immigrants converge to the earnings of other ethnically similar immigrants residing in the host country for more than 25 years. Lastly, some researchers define earnings assimilation as the pure increase in wages through time.

${ }^{13}$ The idea being that assimilation affects only the immigrant group and has a minimal impact on the "French society."
} 
salient. The key feature of integration is tolerance - with moral, social, and legal dimensions and accommodation. In sociology, integration derives from "shared beliefs and practices, social interaction, and shared goals," while in political theory, "integration may be seen as what makes standard majoritarian democracy possible" (Weil and Crowley 1994, p. 112). While integration still is the French legitimate term, it has come to denote, especially by politicians, an interactive process between cultures and the fact that immigration will continue.

Based on the theory of human capital, the economic theory on migration posits that newly arrived immigrants experience an initial disadvantage in the host labour market. During the initial shock of the move (one to ten years), even immigrants who possess higher human capital lag behind natives, due to the nontransferability of their human capital. Nonetheless, they are able to overcome this handicap, to reach economic parity with natives - thus, achieving economic assimilation - and to even surpass the natives. The mechanism of their success is through their additional investment in human capital as they stay longer in the host country along with their innate ability and will to succeed.

The labour market performance of immigrants is strongly influenced by the country of origin, as well as by the host country's admission criteria. At the same time, the labour market performance of immigrants is equally influenced by the host country's economy. During the upswing of the business cycle not only more immigrants will move to a country but this country will also have a strong absorptive capacity, since a prosperous booming economy can offer more opportunities for full participation, and advancement. One would, therefore, expect that the waves of immigrants that arrive during flourishing periods will achieve rapid economic assimilation. France, on the other hand, has always been characterised by rigid labour markets, a 
more centralised economy, relatively high minimum wages, strict regulations to layoffs, high unemployment rates, low labour force participation rates, and an extensive social welfare system. Under these circumstances, one would expect immigrant integration to be slow or not to take place at all.

\subsection{Immigrant Assimilation and Intergenerational Mobility}

One of the very first studies on the earnings of the immigrant groups in France was conducted by Butaud (1972). He carried out a survey on about 1773 men and 386 women workers who were actively involved in the labour market in 1970. His descriptive study revealed that there were substantial earnings differences among the various ethnic immigrant groups. Specifically, he found that Yugoslav immigrants ranked the highest. Not only the salaries of Yugoslav men and women were the highest among all groups but they also had the highest standard deviation. At the other end of the spectrum, Butaud (1972) found the Maghrebian men ${ }^{14}$ who earned the lowest salaries (about 30\% less than Yugoslavs) while they had the lowest standard deviation as well. Spaniard men ranked second and Portugese men ranked third. Among women, Italians ranked second and Portuguese third. The Butaud study also found small earnings differences according to geographic location. Immigrants in the Paris region earned more and immigrants in Provence-Côte d'Azur earn less than in other areas. Nonetheless, Butaud (1972) found that the ethnic salary dispersion was consistently maintained geographically. In sum, already in 1970, a period of favourable economic conditions in France, this study showed that some immigrant groups did not fare as well as others in the French labor

\footnotetext{
${ }^{14}$ Maghrebian women were not in the labour force; only 4 women were in the sample and, thus, there is no reference to them.
} 
market. Butaud (1972) also declared that immigrants from sub-Saharan Africa had low salaries and suffered from unemployment with one in eight workers being unemployed. He concluded that cultural level disparities were the probable cause of low economic performance as every nationality was perceived by natives as being in a distant social scale.

Another one of the early studies on the earnings of immigrants in France was carried out by Granier and Marciano (1975). Based on a 1970 survey by the Ministry of Public Works and Housing and data by INSEE they studied the wages of individual men and women workers as well as the total family earnings of immigrants and tried to compare them to those of French nationals. They found that immigrant men workers were less skilled than native French workers, and heavily concentrated in manufacturing, especially automobile, and construction industries. In their analysis, they first compared the wages of the unskilled and semiskilled immigrants to those of similar French workers. From this exercise, they found that immigrant wages were quite close to those of French. However, when they compared skilled non-manual immigrants to comparable French nationals the wage gap widened and became considerable. Similar to other studies, they found that the wages of immigrant men had a wide dispersion by ethnicity, with Yugoslavs earning $40 \%$ more, on average, than North Africans. This result was also valid for the analysis on the wages of immigrant women. In general, immigrant women were concentrated in domestic services, and in the textile and clothing industries. Women's labour force participation also varied by nationality with Yugoslavs, Spaniards, Portuguese, and Italians having the highest labour force participation rates. Still, compared to men, this study showed that immigrant women were poorly paid. 
An idiosyncratic group of immigrants to France are the Algerian repatriates, or French refugees. Their migration to France was unprecedented, historic, and of a large scale. Some 500,000 refugees alone arrived in France in the summer of 1962. This group comprises the French, ${ }^{15}$ the "French Muslims," and many Jews. Among the first studies to examine the integration of the Algerian repatriates in France is Baillet (1976). Baillet studied the salaried and non-salaried repatriates in both the private and public sectors. With regards to the salaried workers, he found that although about $80 \%$ of them had to change job categories and professions once they moved to France, although they experienced lower salaries and lost the perks they were enjoying in Algeria, they managed to achieve a rapid economic integration through a process of professional mutation. Among the non-salaried workers, he found that the workers in the independent professions - such as lawyers, doctors, and business men - were quite successful in the French labour market, but it was the farmers who had shown an exemplary reintegration. Overall, Baillet (1976) contended that the reintegration of the repatriates was relatively easy, was successfully realised and at a minimum cost. However, he found that there was pronounced differential integration by ethnicity, with Arabs and Berbers performing the poorest in the labour market. Out of all the repatriates in France, he found the Jewish to have experienced the fastest and most successful integration.

In 1992, Tribalat (1996) conducted an important survey on the integration of immigrants within the National Institute of Demographic Studies (Institut National d' Etudes Démographiques, INED) and INSEE. This survey - the Mobilité Géographique et Insertion Sociale (MGIS) - was based on samples drawn from the 1990 census and has since been the

\footnotetext{
${ }^{15}$ They are the former colonists, who are French by birth, often called the pieds noirs. The closest analogy to this group is the ethnic Germans.
} 
principal survey besides the census. The MGIS interviewed 8,900 immigrants from Algeria, Sub-Saharan Africa, South-East Asia, Spain, Morocco, Portugal, and Turkey, who were in France in 1990. This survey also included 2,500 young adults (20-29 years old) born in France whose at least one parent was from Algeria, Spain, or Portugal, and a control sample of the indigenous population. Tribalat's (1996) study concluded that the year of entry, the age at entry, years of residence in France, and professional experience were the key variables for the successful integration and assimilation of the immigrants in France. The striking result in that study was that the gap between the wages of immigrants and natives was the largest in the upper and lower ends of the distribution, while it was not particularly significant in the middle range.

Based on the same MGIS study, Dayan et al. (1996) studied the professional integration of immigrants in the French labour market as well as their professional and social mobility and compared them to the native population. In their longitudinal study that represents more than half of the immigrant population in France, they studied both men and women immigrants who were working during the interview. Overall, they found that immigrants were more often in temporary and precarious employment than the natives, and they were most often dilapidated by unemployment. Among all immigrants, they found women to be more vulnerable in the labour market and mostly hit by unemployment. On the other hand, they found that immigrant men suffered mostly from unstable and precarious employment.

Dayan et al. (1996) ran logistic regressions on the probability of being continuously in stable employment and found that age, years since migration, and years of schooling were the most important determinants of integration into the professional life. These key variables significantly increased the chances of having continuous stable employment. Knowing and 
speaking the French language fluently was the most significant determinant across all specifications. Surprisingly, they also found that the immigrants who kept close ties with the country of origin were better integrated than those who did not. With regards to the country of origin effect, they found that it was crucial for the integration of women only. In particular, Portuguese women were the most integrated into the labour market while women from the Maghreb and Turkey performed the worst. The number of children was also a significant determinant of the professional integration of women. Controlling for education, experience, seniority on the job, and language, they found that the wage differentials between immigrants and natives was minimal - about $5 \%$ - and it was mostly due to the barriers of entry into the labour market. For example, when immigrants joined the labour market they were in the lower tier, working mainly as unskilled blue-collar workers. Further, while immigrants tended to stay in the same jobs they first started with, and they were characterised by absence of promotions, a phenomenon indicative of labour market segmentation.

While young age at entry, years of schooling, French language, and no desire to return to the country of origin were positive determinants of upward mobility, Dayan et al. (1996) found that intergenerational mobility in France was very slow. Surprisingly, they found that intergenerational mobility was higher among women immigrants. Finally, Dayan et al. (1996) found that it was the young immigrants who were more often exposed to the risks and fickleness of the labour market. Depending on their country of origin, immigrants in France have different chances of entering the labour market and of succeeding. Echoing other studies, this study also found that immigrants from Algeria were performing the worst in the French labour market. 
The Glaude and Borrel (2002) study looked at the difficulties that immigrants face when entering the labour market. Based on the latest data from the 1999 census their descriptive study only reinforced findings from previous studies. Among other findings, they also found that there are strong country of origin differences that are evident in every aspect of economic activity. In addition, when they examined the newly arrived immigrants to France and compared them to immigrants with a longer tenure in France they found that, although on average, immigrants who arrived after 1990 resembled the rest of the immigrants, there were substantial differences at the ends of the socioeconomic distribution. The newly arrived immigrants who were at the lower end were worse off than the other immigrants, while those at the upper end were better off than the other immigrants.

The next natural question is whether these findings also apply to the children of immigrants. The incorporation of the second generation immigrants from North Africa resulting from decolonization of Algeria, Morocco, and Tunisia was studied by Alba and Silberman (2002). Analyzing micro-level data from the censuses of 1968, 1975, 1982, and 1990, they examined the integration of the second generation born in France in the period 1958-1990. Based on the characteristics of the parents they were able to distinguish the children of the pieds noirs ${ }^{16}$ from the children of the Maghrebians and compare them to the native French. Their findings demonstrate that there were different trajectories of integration by nationality. While the pieds noirs and their children exhibited signs of rapid integration, the Maghrebians (Arabic or Berber) and their children remaining detached from the labour market. Resounding other studies they

\footnotetext{
${ }^{16}$ The Muslims who fought on the French side in the Algerian war of independence and suffered exile, the harkis, are in this group as well.
} 
concluded that there is a sharp social distinction between the two groups as well as between the two groups and the mainland native French population.

The intergenerational mobility of immigrants was studied by Silberman and Fournier (1999). Their longitudinal study is based on the Entrée dans la Vie Active (EVA) survey, that targets the children of immigrants, especially the children who finished lower level schooling (level 5 and 6; below the baccalaureate level ${ }^{17}$ ). In 1989, EVA interviewed the children of immigrants from the moment they finished school or apprenticeship and followed them for 4 years as they experienced the transition from school to work, and began their careers and professional trajectories into the labour market. The study only looked at immigrant children from the Maghreb (especially Algerians) and Portugal. They paid attention to whether these children had actually left school with a degree (diploma) or not, and tried to capture shipskin effects. In France, apprenticeship is a way to make up for not having a diploma; still few of the immigrant children have followed that track. One explanation is that immigrant children are not properly guided by their parents. Once again, this explanation may not hold for all different national origin groups. Whereas it is true for Algerian children it is not true for Portuguese children. In general, Algerian parents do not have the social capital to help their children enter the labour market. They are usually unskilled blue collar workers, or unemployed, or already inactive and out of the labour force by the time their children are ready to join the labour market. Portuguese fathers, on the other hand, are usually working in small enterprises and have the appropriate connections to help their children in the beginning of their careers.

\footnotetext{
${ }^{17}$ Roughly this is the equivalent of a US high school diploma.
} 
In sum, Silberman and Fournier (1999) found that Portuguese children have better opportunities than Algerian children mainly due to the social and ethnic capital of their parents, as well as to their parents' connections. They found that Algerian children had less often finished the apprenticeship, were more often unemployed, and benefited less by the familial network. Of great concern is the fact that Algerian youth were more often frustrated with their plight and discouraged to participate in the labour market, than other ethnic youth. The study argued in conclusion that social origin is a very important determinant of any kind of success in France while it could not rule out the role of discrimination in the labour market. In effect, discrimination affects male youth more than female youth. Obviously, it is easier for a daughter to escape the blue collar job of the father, than it is for a son. As a last point of reflection Silberman and Fournier (1999) discussed the role of residential location of immigrants and their children. They found that part of the difficulty immigrants face in penetrating the professional life is their isolated residential location in the suburbs and the lack of transportation means whether mass or individual. It is also often the case that immigrants lack the financial means necessary to relocate and take advantage of greater employment opportunities.

In the same period, Richard (1997) analysed the Permanent Demographic Sample (Echantillon Démographique Permanent EDP) to measure the intergenerational labour market progress of immigrants. The EDP is a census-based panel survey that, on average, comprises a $1 \%$ sample of all immigrant groups. It has information on a person's nationality in relation to his/her labour market position. It also contains valuable information on parents and sons with a sample of 15,345 children, who were four to eighteen years old in 1975. Controlling for age and educational attainment, he examined the wages of immigrants and compared them to those of natives. Based on this panel study he found that the poor performance of the young immigrants 
in the labour market is undoubtedly due to their ethnic background, which is negatively correlated with labor market opportunities. Richard (1997) found considerable divergence in performance between immigrants from EU and from other countries. Especially, he found that young workers with a Maghreb background often face labour market discrimination as they encounter unequal employment opportunities and permanent difficulties in penetrating the labour market.

France has a national education system, whereby the teachers are federal employees of the Ministry of Education, and education is based on 4 principles: equal access, non-discrimination, neutrality, and secularity. However, in practice, the educational system has affected immigrant children disproportionately. In the 1960s a segregated system resulted in only $10 \%$ of the working-class children to go to the college (the first four years of secondary education) and only $6 \%$ to the university. The 1975 reform made it possible for all children to go to college, but still only $6 \%$ go to the university (Weil and Crowley 1994).

Over the years, it appears that French schools have lost their power to "assimilate" immigrant youth, to ensure their upward socioeconomic mobility, or at least to even out socioeconomic differences between immigrant and native children, leading some immigrant youth to drop out of school and turn to crime, and others to assert their religious/cultural identity. Some fear that this may lead to the loss of identification as "French." Loss of French identity coupled with the change in the French law, that requires youth to choose to become French nationals between the age of 16 and 21 , could increase isolation and intensify identity crises. Others caution that even several programmes initiated to help youth have not succeeded in facilitating the transition from school to work. While buildings have been allocated for that purpose and 
teachers assigned to special neighbourhoods, immigrant and disadvantaged children have not benefited (IGAS 2002).

Vallet and Caille (1999) studied the scholastic achievements of the immigrant children. In their panel study they followed children during their high school years until they received their baccalaureate. Controlling for parental background, social origin, and size of the family, they found that immigrant children performed as well as French children and they even outperformed French children in mathematics. This finding lead them to conclude that it is the inequality of the conditions of being brought up in an environment with social handicaps and not the individual ability that makes a difference in the scholastic performance of children. Within the frame of intergenerational research, the Héran (1996) study also found that, everything else equal, the children of immigrants perform at least as well as the other native children. In fact, they proved that the observed inequalities (or gaps in performance) were due to the inequality of the living and social conditions as well as to a discriminatory educational system. Although the latter is rather hard to prove, it often happens that if the teachers anticipate that the immigrant children will fail in certain fields, they will try to dissuade them from pursuing these fields. Children who have no proper guidance from home find themselves in limbo unable to reach up to their full potential.

\subsection{Diverse Immigrant Groups in France - and the Self-employment of Immigrants}

Even though migration to France is mostly tied to its former colonies, migration from south-east Asia (Vietnam, Laos, Cambodia, and China) along with Lebanon and Turkey is becoming very prominent. In addition to the traditional immigrants from the ex-colonies and the 
Southern European labourers, the country-mix has shifted over the last two decades. In general, these diverse groups bring diverse skills and attitudes. Some groups exhibit a higher proclivity to entrepreneurship, for example. The argument is that immigrants are more likely to start their own business, because they are more willing than natives to assume risks. For many immigrants, self-employment is a way of economic and social upward mobility, a way to avoid discrimination, as it also gives them the satisfaction of being one's own boss. By starting out a small business immigrants can create jobs in addition to occupying them, and by hiring other people for their companies they can even lower unemployment.

Dayan et al. (1996) studied the probability of immigrants going into self-employment. They found that among all immigrant groups, Turks had the highest propensity to become selfemployed. Among the immigrant groups that are well represented in the self-employment category are the Chinese. Chinese migration to France became important in the 1980s. Currently, about 200,000 Chinese immigrants live in France. The performance of the Chinese immigrants in France is studied by Ma Mung (2002). He found that Chinese immigrants are well represented in the small-scale entrepreneurial sector. In 1990, the Chinese enterprises in the Parisian area alone employed $40 \%$ of the active Chinese population in that area and constituted an important economic circuit. Chinese enterprises are usually of a small and familial setting and are characterised by being transnational. In his study, Ma Mung (2002) showed that Chinese entrepreneurs know the market, and know where to open a business; they know how to circulate the necessary capital to open a business; and they know how to circulate merchandise beyond country boarders. Finally, they have a great capacity to react swiftly to the macro fluctuations by changing and adjusting their import-export endeavours. Overall, Chinese entrepreneurs in France are faring quite well. 
While in the 1970s immigrant women were practically invisible, and forgotten by social scientists, by the end of the last century $45 \%$ of the immigrant women aged $15-60$ were active in the labour market. At the same time, however, these women were affected by long term unemployment 3 times more than the French women. Immigrant women also suffer from various obstacles - financial, cultural, social, institutional, and legislative. A study on immigrant women's employment and the creation of employment was conducted in 2000 by Hükum and Le Saout (2002). Creating employment in this study means that these women either form an enterprise, an independent profession, or an association. The Hükum and Le Saout (2002) study focussed on 158 women from the Maghreb countries, Turkey, and Sub-Saharan Africa, who were in France for more than 12 years. They concluded that immigrant women are capable of transferring their professional know-how into a variety of economic activity. These immigrant women are characterised by an entrepreneurial ethos, which distinguishes them by their superior ability to mobilise their social, ethnic, and personal resources in order to succeed in an oftenfragile labour market. For these immigrant women, becoming self-employed was a way of achieving a respectable social status even though it does not necessarily mean that they become wealthy.

Baillet (2003) studied the occupational sorting of Algerians in Paris and the Parisian region. After the 1982 census, it is clear the number of Algerians in Paris has decreased. While this might reflect their becoming French and disappearing from the statistics as immigrants, they still remain the second largest immigrant group after the Portuguese. Baillet (2003) found that there has been a shift in their occupations from blue collar workers to employees to small businesses. Especially after 1984, Algerians, and Kabyles in particular, are increasingly sorted into the commerce and craft occupations. When they are in the trade-business sector, they own 
small hotels, restaurants, and coffee shops. However, even those who are in the blue collar or labourer occupations are mostly skilled and are in the iron and steel industry. In sum, for Paris and the Parisian region, Algerians (especially after the halt on immigration) are increasingly moving away from the blue collar labourer milieu and moving into the 'petite bourgeoisie en declin' ( $\mathrm{p}$ 98) or the low middle class in decline.

\section{$\underline{4.4 \text { Remigration Bias }}$}

All studies on immigrant integration and assimilation are based on the immigrant population that is living in the host country at the time of the survey, ignoring the characteristics of those immigrants who have left the host country before the census or the survey. Estimations of this kind might suffer from remigration bias and draw the wrong conclusions; the rational being that the degree of assimilation of the return migrants remains unknown. France does not have population registers and immigrant departures are not recorded in the French statistical system. ${ }^{18}$ This makes it extremely difficult to accurately measure the exits of immigrants. Some crude estimates on return migration in the 1970s show that the number of immigrants who left France to return to their home country was as high as $60,000-70,000$ per year. Later, these numbers decreased mainly due to the increase in family immigration. ${ }^{19}$ For the Algerian repatriates, in particular, some estimates show that $24 \%$ of those who arrived in France during 1962-1968 returned to Algeria during 1968-1975.

\footnotetext{
${ }^{18}$ Only forced and assisted departures are recorded.

${ }^{19}$ Since 1975 the French government has given monetary incentives to immigrants so they return to
} their home country. More than 230,000 have taken advantage of this aid and have returned home (Le Moigne and Lebon 2002). 
Based on the EDP, the INSEE (1999) published a study on the emigration patterns of immigrants in France. The EDP started in 1968 and, thus, contains information on the last 5 censuses. In this study return migration was defined as an absence from two consecutive censuses. This study found that from the immigrants who arrived in France between 1962 and 1968, one in four immigrants has returned back home within the first ten years of their arrival in France. Naturally, return migration rates varied substantially by nationality with more Spaniards returning home than Italians or Portuguese. This study also found similar return rates for the immigrants who arrived in France before 1962. For example, 28\% of the Portuguese who arrived in France before 1962, returned to Portugal during the period 1975-1982. In contrast, return rates declined for those who arrived between 1968 and 1975. Less than 20\% of Algerians and Moroccans returned home while return migration by EU national was appreciably higher (INSEE 1999).

A parallel attempt to account for the return migration rates when studying the immigrant population was carried out by Rouault and Thave (1997). They used longitudinal data of the EDP that have information on the entry and exit of the same immigrants from one census to the next since 1975. Their estimation of return migration rates is of the order of $30-40 \%$, which is quite considerable. The Thierry (2001) study on return migration focussed on the renewal frequency of one-year residence permits. These permits were issued to foreigners authorised to enter France during the period 1994-1996 by the Department of Interior. Based on the non renewal of permits, he estimated an average emigration rate of 35\% during that first year and this rate varied strongly by nationality. This rate was higher for the immigrants from other EU countries and lower for the immigrants coming from third countries $(54 \%$ versus $21 \%$ 
respectively). However, these estimates might be inflated due to the inclusion of foreign students in the data. ${ }^{20}$

An innovative approach to calculate remigration rates was undertaken by the HCI. This study focussed on retirement pensions data. The study found that many immigrants return to their home country when they retire. During the 1990s, an impressive number of 90,000 retired Algerian immigrants returned home. Spaniard and Portuguese retirees also reached a high average annual return, with 8,100 returnees and 3,800 returnees respectively. Italians had the lowest number of returnees (1,300 per year), probably because not many Italians lived in France in the 1990s. The calculated average annual departure number for Moroccans was also low at 1,400 immigrants. In all likelihood this is because Moroccans are more "recent" immigrants and are a younger group far from retiring age (Héran 2002).

The review of the aforementioned studies leads to the following conclusion. It appears that immigrants in France are not as socially or as economically integrated as it was expected or desired. Moreover, they are often faced with unequal employment opportunities as well as with an unprecedented rise in unemployment. Immigrant assimilation in France varies considerably by nationality, and most studies argue that this is rather the result of integrating factors. For certain groups - such as the Maghrebians - assimilation is rarely realized. In the new century, immigrants from the Maghrebian countries, face even fewer prospects of social and economic assimilation. Whereas some studies show that self-employed immigrants fare well, most studies

\footnotetext{
${ }^{20}$ In 1997 , foreign students from outside the EU comprised about $11 \%$ of all University students enrolled in France.
} 
agree that there is no actual intergenerational mobility. Still, the sample of studies is too small and suffers from several biases: cohort effects, remigration bias, selection bias, etc.

\section{Impact on the Labour Market}

The crux of the debate of the impact of immigrants on the labor market centers upon the following question: does the arrival of immigrants in the host country and in a particular area depress the wages of the natives or of other immigrant residents, and does it increase their unemployment level? Inflated by right-wing politicians, there is a growing sentiment that immigrants are stealing away jobs from natives. In France, a country with chronic unemployment rates around $10 \%$, immigration has come to be equivalent to unemployment, and immigrants in France have become the escape goat.

\section{$\underline{5.1 \text { Impact on Employment, Income Levels, and Internal Mobility }}$}

The argument here centres upon the degree of substitutability or complementarity between the skills of immigrants and natives. However, the impact also depends on the flexibility of wages, the consumption behaviour of immigrants, etc. In the US, the vast literature on the impact of immigrants on the wages and employment opportunities of natives does not provide support to the popular belief that there are adverse effects from immigration (Friedburg and Hunt 1995).

Brücker et al. (2002) studied this question for Europe. Their study was based on the European Community Household Panel (ECHP) of all EU country members. Looking at most 
European countries - including France - they found, at best, a negligible impact of migration on wages and on the employment of natives. Another interesting finding of the Brücker et al. (2002) study is that they could not confirm the popular belief that the more generous countries in terms of social welfare systematically attract the less qualified and less educated immigrants.

Angrist and Kugler (2002) estimated the effect of immigrant flows on native employment in Western Europe by focussing on the role of the labour market institutions. They examined the extend to which labour market flexibility - such as employment protection, high replacement rates, firing costs, rigid wages, and business entry costs - affects the employment consequences of immigration in the host labour markets. Their analysis is based on panel data for 18 countries' labour-force surveys for the period 1983-1999 including France. Their OLS and IV estimates showed that a $10 \%$ increase in the foreign share would reduce the employment rates of the natives by $0.2-0.7$ of a percentage point. They concluded that while in the short-run restrictive labour market institutions might protect native workers, in the long-run they fail to protect them from job loss and can aggravate job losses due to immigration.

Specifically for France, only a handful of studies has looked at the impact of immigrants on the labour market. Among the first researchers to study the phenomenon of the labour market impact and internal migration patterns was Puig (1981). By examining, among other groups, the presence of young repatriates in France, the question he tried to answer was where do people move to, and why do people move away from some regions. Looking at the interregional migration of the active population of France's 21 regions, he examined this question for the periods 1962-1968, and 1968-1975. He studied the impact of the repatriates from Algeria for the period 1962-1968 only. By decomposing the active population by age - with a cut off at 30 years 
of age - and by estimating gross immigration equations, he found that people move to areas where average salaries are higher and employment vacancies exist, and they move away from areas with a high percentage of young workers. Moreover, he found that people move away from areas where the repatriates live. He concluded that the repatriates engendered unemployment and discouraged internal immigration to regions where repatriates were concentrated.

Taking advantage of the natural experiment of the Algerian independence in 1962, Hunt (1992) also studied the impact of the Algerian repatriates on the French labour market. In particular, she estimated the impact of repatriates on unemployment, labour force participation, and wages of the non-repatriates, as well as on the migration decisions of other groups. Based on census data, she estimated cross-sectional regression models and controlled for education, age, and industrial and regional differences. She found that the repatriates, who represented $1.6 \%$ of the labour force in 1968, were over-represented in skilled occupations, and chose to locate in regions with similar climate to Algeria, and regions where previous repatriates form Algeria were already located. Although within a couple of years of their arrival the repatriates suffered a high unemployment, she found that the repatriates caused only a small increase in the unemployment of non repatriates (an increase of 0.3 percentage point at the most). With regards to the impact on the wages, her estimates from several specifications showed only weak evidence that wages fell in response to the arrival of the repatriates. At most, average annual salaries were lowered by $1.3 \%$. The presence of repatriates had no effect on the labour force participation of the non-repatriates either. Lastly, with regards to the effects on the migration decisions of other groups, she found that the presence of repatriates in a region had no significant effect on internal migration decisions, but exerted a positive and strong effect on international migration decisions. However, all things considered, the total impact of the repatriates was seen 
to be about zero, meaning that the arrival of immigrants in an area hardly affected the salaries or employment levels of the natives.

A more recent study, Gross (1999), investigated the effects of the flows of immigrant workers in the French labour market. This study focussed on the period from the mid-1970s to mid-1990s. In a macroeconometric setting and using a Keynesian model of disequilibrium he estimated equations on unemployment, real wages, and labour force participation. His findings revealed that, in the short run, the arrival of immigrants can raise aggregate wages through the complementarity of immigrants and natives and, thus, increase unemployment. However, this effect is short-lived and similar to an increase in domestic labour force participation. In the long run, immigrant workers and their families lower the unemployment rate permanently, suggesting that the demand for goods and services by immigrants creates more jobs than they occupy. Gross (1999) also found that this result holds for immigrant workers, amnestied immigrants, and the flow of immigrant families. Finally, and contrary to the economic theory, he found that using amnesties as a channel for immigration is not detrimental to the labour market. All in all, he found little evidence for displacement effects due to migration, concluding that immigrant flows are not responsible for France's high unemployment rates.

A later study on the immigrant evolution on the French labour market by Brun (2003) also showed that a small sample of legalised or amnestied immigrants performed a lot better after they were granted amnesty. These amnestied immigrants were able to find better jobs and increase their wages. For example, whereas before amnesty $44 \%$ of these immigrants had incomes below 610 Euros per month and only 18\% earned more than 915 Euros per month, the 
situation was almost reversed after amnesty with 14\% earning less than 610 Euros and 37\% earning more than 910 Euros.

These findings warrant a further comment on amnestied immigrants. The general presumption - dictated by economic theory - is that because economic migrants are selected according to their skills they have a higher probability of succeeding in the host country's labour market and achieve an accelerated economic assimilation. Obviously, illegal migrants do not seem to qualify for this theory. However, amnesty is typically given to successful illegal migrants, e. g. those who have found work over a particular period of time $e^{21}$ and have proven that they are desirable participants of the labour force. Consequently, amnestied immigrants are de facto selected by the labour market forces. This type of selection should, thus, be more efficient than if imposed by a public bureaucracy that has insufficient knowledge about the labour needs of the economy. It is, therefore, quite possible that a strategy of allowing illegal migration with a policy to provide amnesty can be efficacious and efficient under certain circumstances, and France has often used amnesties as a means of selecting immigrants into the labour market.

Studying the period 1990-1997, Jayet et al. (2001) estimated the effects of immigration on the probability of employment and the wage levels of natives. They employed data from the Employment Survey, and estimated a Heckman-2-step model of selection while conducting a separate analysis for men and women immigrants. They tested their model on the French born and on 5 separate groups of immigrants - naturalised French, Southern Europeans (including

\footnotetext{
${ }^{21}$ For France, one of the requirements for eligibility for amnesty in 1983 was to have worked in France for at least a year.
} 
Italians, Portugese, and Spaniards), other Europeans, Maghrebians, and the rest of all other foreigners. They further considered 5 levels of professional qualification: upper administrative and managerial positions, intermediate professions, employees, skilled workers, and unskilled workers. Their results on the probability of employment for the male samples showed that the presence of immigrants in a locality had no effect on the probability of employment of the natives. For the female samples, they found that there was an effect but this effect depended on the nationality of the immigrants. In particular, the presence of the group labelled other foreigners had a positive impact while the presence of Maghrebians had a small negative impact on the probability of employment of women in France.

With regards to the impact on the incomes of natives, Jayet et al. (2001) showed that, in general, for both men and women, there were small effects. Looking closer at the socioprofessional categories, they found that, for men, there was a significant effect on income but only for the skilled workers and the intermediate professionals. In contrast, they found no effect for the categories of unskilled workers and employees. For women, they found some significantly positive effects that were related to the presence of the other Europeans group, and to the presence of other foreigners group. For women only, and for the years 1994-1996 Jayet et al. (2001) obtained negative effects on the incomes of natives attributed to the presence of Maghrebians. In sum, this study showed that the presence of immigrants did not cause the incomes of the natives to decline for neither men nor women, and that the migration patterns of immigrants and natives in France are similar to those results for the US. 


\subsection{Natives' Sentiments and Business Cycle Effects}

With the exception of the poor performance of the Maghrebians, the leitmotiv of the previous section has been that over the last 40 years, immigrants in France do not constitute a threat to the labour market or to the social fabric of French society. This finding holds true for both legal and illegal workers, and for immigrants who migrated for work or family reasons. However, natives' sentiments towards immigrants are often negative.

Based on data from national surveys from 1970 through 1995 Simon and Lynch (1999) tried to link public opinion towards immigrants and immigration policies. They found that public opinion about immigration policy varies over time and that the desire to restrict migration through policy is not consistently related to negative sentiments against immigrants. While in 1988 sixty-four per cent of French felt that France is a country that welcomes foreigners, in 1991 seventy-one per cent complained that there are too many Arabs in France. In 1993 sixty-seven per cent of French ascertained that France risks losing its national identity and something must be done about immigrants. At the same time, seventy-six per cent of French acknowledged that immigrants do not take jobs away but they do the work the French refuse to do. Among immigrant groups, northern Europeans were the most liked by French while Maghrebians, Turks, Persians, and Black Africans were the least favoured. Overall in this study, the French expressed at best ambivalent sentiments towards immigrants and when they were vociferous against a specific ethnic group it was because of the social and cultural distance between them.

Fetzer (2000) used public-opinion surveys on opposition to immigration and polls on support for the French "Front National" to examine the natives' sentiments towards immigrants 
in France in the late 1980s and mid-1990s. His analysis involved multivariate regression models and Tobits employing interesting demographic, economic, and cultural variables. He tested 2 hypotheses: (1) the economic self-interest belief that if the natives are unemployed, if they suffer declining personal finances, and they lack advanced education then they oppose migration reflecting their narrow, material self-interest, and (2) the theory of marginality according to which, if natives feel marginalised and alienated they are more likely to be sympathetic to immigrants in the spirit of solidarity of the likes and reduce anti-immigration sentiments. His results provide minute support for the economic self-interest theory, and small support for the economic marginality theory. Namely, he found that individual unemployment did not have any effect on nativism. Nevertheless, he found confirmation of the cultural interpretation of the marginality theory.

In general, Fetzer (2000) found that being a racial, ethnic, or religious minority decreases anti-immigration sentiments. Moreover, he found that females and individuals of foreign origin have weakened anti-immigration sentiments. In his conclusion Fetzer (2000) stated that opposition to immigration "has as much to do with symbolically delegitimating the values and cultures of immigrant minorities as with preventing the foreign-born from taking natives jobs" (p. 18). Lastly, this study emphasised the role of culture in nativism.

Based on individual data from 12 OECD countries, Bauer et al. (2000) found that natives favour immigration in countries that are positively selecting immigrants according to economic motives. This led them to conclude that an effectively selective migration policy can attenuate natives xenophobia and hostility against immigrants, while it can allow politicians to increase the number of humanitarian immigrants without risking re-election failure. 
The last question I examine in this review essay is whether it is the migration policy or the business cycle that determines the flow of immigrants and their employment patterns in the host country. Zimmermann's (1996) study on European migration showed that migration is strongly driven by business cycle effects as it occurred both in France and Germany from the 1950s until the halt in recruitment in the early 1970s. However, he also found that after the recruitment of immigrants ended, migration from most home countries responded less to the business cycle. Surprisingly, and contrary to general expectations, he found that humanitarian migration was also affected by the business cycle in the host countries.

Moreover, not only migration per se is related to the host country's business cycle, but the performance of immigrants is also affected by the stage of the business cycle they face at the time they enter into the host country labour market. It is also true that immigrant performance continues to be influenced by the macroeconomic conditions in the host country during their stay. The rationale is that immigrants are more vulnerable and more cyclically sensitive to the macroeconomic conditions than the native born. Entering the host country during a period of high unemployment has adverse effects on the earnings of immigrants but these effects are temporary and disappear with additional years in the US (Chiswick and Miller 2002).

For France, Hollifield (1990) tested the argument that immigration and foreign employment are a function of changes in labour market conditions, employers' hiring practices, and policy. In his time-series analysis with a one-year lag, he considered economic migrants, seasonal workers, and family reunion migration. He found that both changes in labour market conditions and in the hiring practices of employers have had substantial impact on the levels of permanent worker migration. On the other hand, he found that changes in policy had a very 
marginal impact on worker migration. With regards to seasonal migration, he found that although the social and economic conditions had some effect, the policy measures have contributed to a loss of state control over seasonal migration. Lastly, with regards to family migration, he found that family members do eventually join the labour force and their flows are, thus, very sensitive to employers hiring practices. Family reunification levels are also contingent upon social and economic conditions in France. Overall, the policy changes in France have had only marginal effects on migration while labour market conditions have a substantial impact on migration.

\section{Conclusions}

Over the last fifty years, France has received numerous waves of immigrants with different origins, cultures, aspirations, and motives. French immigration policy has been to accept people that either had accepted or were willing to accept French language and culture. Such a policy seemed easy to implement, since the major source countries of immigration were the former colonies. However, while immigrants typically migrated from the former French colonies, there were also economic migrants actively recruited by the French government over some periods. The French "creuset" has functioned efficaciously until the last third of the twentieth century. In the seventies, when economic conditions in France changed and became more difficult, immigration policy became increasingly tight. After the halt of recruitment, family unification became a major channel of immigration to France albeit illegal immigrants and refugees became also important. 
The socioeconomic portrait of the migrants in France by the year 2000 dictates that they have fewer skills than the natives and their occupational status is below that of the natives with comparable skills. The labour market performance of certain nationalities, in particular, persistently lags behind that of natives. Even when some nationalities manage to perform well in monetary terms, their insertion into the social hierarchy is minimal. Immigrants often live in poor areas of large cities, are disproportionately affected by unemployment, and are more vulnerable to economic crises. The majority of the immigrant population in France is manual workers and there is only minute intergenerational mobility.

Looking back at the French historical experience with regards to migration, it appears that economic assimilation has not taken place to a full extent. Economic integration is a necessary although not sufficient condition for full integration. It denotes opportunities, fairness, and smooth functioning of the labor market that lead to success. Whereas some studies have shown that some immigrant groups have achieved success, most studies showed that immigrants in France are performing very poorly compared to natives. Looking at the income distribution, it is noteworthy that while the middle class is performing comparatively similar to French natives, immigrants in the upper and lower ends are doing much worse than their French counterparts. Moreover, there are often substantial earnings differences among the various immigrant groups, with the Portuguese, the naturalised, and even the amnestied immigrants faring well and the Algerians faring badly. From the surveyed studies in this chapter, it is clear that the socioeconomic position of immigrants, who are not from EU countries, is problematic. Immigrants suffer from high unemployment and when they are employed they occupy unstable, low-wage jobs with low possibilities of advancement. 
With regards to the children of immigrants most studies have shown that immigrant children consistently lag behind French children. However, controlling for social, ethnic, and cultural background, immigrant children would have the same academic performance and labour market success as the French children. With the exception of the Portuguese children, there is no sufficient intergenerational mobility. Whereas some studies alluded to discrimination as the culprit, all studies concluded that Algerian youth were more often frustrated with their plight and discouraged to participate in the labour market, than other ethnic youth.

Most empirical findings on the impact of immigration on natives suggest that immigration is not harmful but, at the same time, immigrant contribution to economic growth is rather modest. This review showed that there is no consistent evidence that immigrants crowd out natives from the labour market. The few studies on this theme, confirm that there are no significant displacement effects, that there is no correlation between immigration and unemployment, and that the wages of natives do not decline due to the presence of immigrants. Nonetheless, natives' sentiments towards immigrants are often negative. Whereas these sentiments can be inflated and exacerbated by right-wing politicians, some studies point to the social and cultural distance between immigrants and natives as a possible reason. Lastly, immigration and economic integration are interlinked to the business cycle.

A recurrent theme of the surveyed studies is the allusion to wide-spread discrimination and geographical segregation in France. Unlike the US, it is not the skin colour that interferes with the acceptance and embracing of immigrants in the French society. It is rather the different culture. Racial discrimination is a key factor for the poor labour market performance of immigrants and their children as "an estimated $30-60 \%$ of immigrant children face acute socio- 
economic marginalization" (Hargreaves 1996, p. 612). In addition, some sort of operating statistical discrimination hinders the full potential of immigrants and their children. Some argue that this second-class status bolsters the longing and the languishing of the home country's culture and the appealingness of the Islam (where they can find consolation) and further contributes to their marginalisation and isolation form mainstream society. Although the results of most studies on young immigrants are consistent with the possibility of discrimination it could also be that other labour market mechanisms are at work. Many studies point to the fact that a better selection and integration of immigrants by the French government would have boosted the economic performance of immigrants, would have alleviated labour market stagnation, and would have eased social and political tensions. However, as Angrist and Kugler (2002) argued, it is the reduced labour market flexibility that "makes immigrant absorption more painful" (p. 29).

Migration remains both a political phenomenon, and an institutional construct. Contrary to the spirit of the French migration policy, this review has revealed that immigrants in France have multiple cultural identities. Since the early-1970s, both the right and the leftwing governments in France have unsuccessfully tried to control migration. Part of this failure might stem from a weak implementation of integration policy. While alternating between a laissez-faire and a restrictive immigration policy, there has been a systematic oversight of the needs of the labour market resulting in a significant gap between policy goals and outcomes. The inability to incorporate migrants successfully in the economy and the labour market is probably more of the reason of failure.

France is inextricably bound to its immigrant force, and immigrants continue to arrive in France. Many immigrants and their descendants continue to live in France and are ready and 
willing to contribute to France's economic prosperity. However, they often experience forms of social stigmatisation. Even worse, oftentimes, newly arrived immigrants are treated with disdain and fear by the previous waves of immigrants. Can France in the new century succeed in integrating its minorities of foreign origin in a way to take advantage of this vibrant and promising manpower in the labour market and to benefit from this younger and high fertility foreign population?

The lesson from the French experience is that assimilation through cultural and political venues is not enough. The low economic possibilities of the French labour market since the early 1970s were not conducive to the economic integration of immigrants. Cultural and economic integration should be intertwined to be successful. France should understand the power of ethnic networks and exhibit more religious tolerance as she should recognise the social embeddedness of the immigrants and their families. France should take pride in her multicultural society, embrace this "mosaic," and make the French national identity compatible with the other forms of identity.

Immigration management is a very sensitive issue. The challenge ahead for France is to encourage and foster the economic and social integration of all its immigrants. France should reorient its policy in a way that it is beneficial to all. As Zimmermann (1995) pointed out "immigration was largely beneficial in the past" and it can be advantageous in the future. France is a developed country with the ability and flexibility to absorb its foreign newcomers, and has proven to do so in the past with the repatriates. 
In conclusion, there is substantial need for further studies on immigrants in France. First, while there is some research on the assimilation and integration of migrants and their effects on the natives, the findings need further support and often better treatment by using advanced econometric techniques and more appropriate data. Second, there are a few questions that have been completely overlooked by the French literature: Does immigration have fiscal implications, e.g. does immigration increase or reduce the public deficits? How do migrants affect the social welfare system and income redistribution? How can we understand the political economy of immigration? 


\section{BIBLIOGRAPHY}

Alba, R. and R. Silberman (2002) 'Decolonization immigrations and the social origins of the second generation: the case of north Africans in France', International Migration Review, 36 (4), $1169-1193$

Angrist, J. and A. Kugler (2002) 'Protective or counter-productive? European labour market institutions and the effect of immigrants on EU natives', CEPR Discussion Paper, 3196, London: CEPR

Baillet, P. (1976) 'Les rapatriés d'Algérie en France', Notes et Etudes Documentaires, 42754276, Paris: La Documentation Française

Baillet, D. (2003) 'Le travail des Algériens à Paris depuis 1945', Migration Société, 15 (85), 7898

Bauer, T., M. Lofstrom and K.F. Zimmermann (2000) 'Immigration policy, assimilation of immigrants, and natives' sentiments towards immigrants: Evidence from 12 OECD countries', Swedish Economic Policy Review, 7 (2), 11-53

Brun, François (2003) 'Les immigrés et l' évolution du marché du travail en France', Migration Société, 15 (85), 67-78

Brücker, H., G.S. Epstein, B. McCormick, G. Saint-Paul, A. Venturini and K.F. Zimmermann (2002) 'Managing migration in the European welfare state', in T. Boeri, G. Hanson and B. McCormick (eds.), Immigration Policy and the Welfare System, New York: Oxford University Press

Butaud, J.-P. (1972) 'Les resources des travaileurs étrangers', Hommes et Migrations, 827, 3-24 Chiswick, B. R. and P. W. Miller (2002) 'Immigrant earnings: Language skills, linguistic concentrations and the business cycle', Journal of Population Economics, 15, 31-57 
Dayan, J.-L., A. Echardour and M. Glaude (1996) 'Le parcours professionnel des immigrés en France: une analyse longitudinale', Économie et Statistique, 299, 1996-9, 107-129

Deneuve, C. (2002) 'Besoins de main-d'œouvre des entreprises et recours à l' immigration: quelles perspectives?', in F. Héran (ed.) Immigration, marché du travail, intégration, Paris: Commissariat Général du Plan

Fetzer, J.S. (2000) 'Economic self-interest or cultural marginality? Anti-immigration sentiment and nativist political movements in France, Germany and the USA', Journal of Ethnic and Migration Studies, 26 (1), 5-23

Friedburg, R. and J. Hunt (1995) 'The impact of immigrants on host country wages, employment, and growth', Journal of Economic Perspectives, 9, 23-34.

Glaude, M., and C. Borrel (2002) 'Les immigrés et leurs descendants sur le marché du travail: un regard statistique', in F. Héran (ed.) Immigration, marché du travail, intégration, Paris, France: Commissariat Général du Plan

Goux, D. and E. Maurin (2000) 'The decline in demand for unskilled labor: An empirical analysis method and its application to France', Review of Economics and Statistics, 82 (4), 596607

Granier, R. and J.P. Marciano (1975) 'The earnings of immigrant workers in France', International Labour Review, 111 (2), 143-65.

Gross, D.M. (1999) 'Three million foreigners, three million unemployed? Immigration and the French labor market', International Monetary Fund Working Paper, WP/99/124, Washington D.C.: IMF.

Haus, L. (1999) 'Labor unions and immigration policy in France', International Migration Review, 33 (3), 683-716

Héran, F. (1996) 'L' école, les jeunes et les parents', Économie et Statistique, 296, 5-15 
(ed.) (2002) Immigration, marché du travail, intégration, Paris:

Commissariat Général du Plan

Hargreaves, A. G., (1996) 'A deviant construction: the French media and the 'Banlieues', New

Community, 22 (4), 607-618

Hollifield, J. F. (1990) 'Immigration and the French state: Problems of policy implementation', Comparative Political Studies, 23 (1), 56-79

Hükum, P. and D. Le Saout (2002) 'Les femmes migrantes et la création d' activité', Migrations Etudes, No. 104.

Hunt, J. (1992) 'The impact of the 1962 repatriates from Algeria on the French labor market', Industrial and Labor Relations Review, 45 (3), 556-572

IGAS (2002) 'Le rapport annuel de l'IGAS 2002', L'inspection générale des affaires sociales, La Documentation Française: Paris

ILO (1998) 'The effectiveness of integration policies towards immigrants and their descendants in France, Germany, and the Netherlands', Geneva: ILO

INSEE (1999) 'Regards sur l'immigration', Synthèses, 30, Paris: INSEE

Jayet, H., L. Ragot and D. Rajaonarison (2001) 'L' immigration: quels effets économiques?' Revue d'Économique Politique, 111 (4), 565-96

Le Moigne, G. and A. Lebon (2002) L' Immigration en France, Paris: Presses Universitaires de France

Ma Mung, E. (2002) 'La complexité des migrations des populations d' origine chinoise', in F. Héran (ed.) Immigration, marché du travail, intégration, Paris, France: Commissariat Général du Plan

Puig, J.-P. (1981) 'La migration régionale de la population active', Annales de l'INSEE, 441981, 41-72 
Richard, J.-L. (1997) 'Unemployment among young people of foreign origin in France. Ways of measuring discrimination', in On the way to a multicultural society? The Siena Group Seminar on Social Statistics, Bern: Bundesamt für Statistik.

Rouault, D. and S. Thave (1997?) 'L' estimation du nombre d' immigrés et d' Enfants d' immigrés', INSEE Méthodes, 66, Paris: INSEE

Silberman, R. and I. Fournier (1999) 'Les enfants d' immigrés sur le marché du travail: Les mécanismes d'une discrimination sélective', Formation-Emploi, 65, 31-55

Simon, R. J. and J. P. Lynch (1999) 'A comparative assessment of public opinion towards immigrants and immigration policies', International Migration Review, 33 (2), 455-467

SOPEMI (2001) 'Trends in International Migration: Continuous Reporting System on Migration, Annual Report', Paris and Washington, D.C.: OECD

Tapinos, G. (1975) L' immigration étrangère en France: 1946-1973, Paris: Presses Universitaires de France.

Thierry, X. (2001) 'La fréquence de renouvellement des premiers titres de séjour’, Population, $56(3), 451-468$

Tribalat, M. (1996) De l'immigration a l'assimilation: Enquête sur les populations d'origine étrangère en France, Paris, La Decouverte/INED

Vallet, L.-A. and J.-P. Caille (1999) 'Migration and Integration in France: Academic Careers of Immigrants' Children in Lower and Upper Secondary School', Paper presented at the European Science Foundation Conference in Obernai, France

(1995) 'Les carrières scolaires au collège des élèves étrangers ou issus de

l'immigration', Education et Formations, 1995-40, 5-14

Weil, P. and J. Crowley (1994) 'Integration in theory and practice: a comparison of France and Britain', West European Politics, 17 (2), 110-127 
Wihtol De Wenden, C. (1994) 'The French Response to the Asylum Seeker Influx, 1980-93', The Annals of the American Academy of Political and Social Science, 534, 81-90

Zimmermann, K. F. (1995) 'Tackling the European Migration Problem', Journal of Economic Perspectives, 9 (2), 45-62

(1996) 'European Migration: Push and Pull', International Regional

Science Review, 19 (1-2), 95-128 
Table 1: Population by Nationality and Place of Birth ${ }^{1}$

$\begin{array}{lccc} & \text { Born in France } & \text { Born Abroad } & \text { Total } \\ \text { French at Birth } & 97.1 & 2.9 & 100 \\ \text { Naturalised Citizens } & 34.0 & 66 & 100 \\ \text { Total French Citizens } & \mathbf{9 4 . 4} & \mathbf{5 . 6} & \mathbf{1 0 0} \\ \text { Foreigners } & 15.6 & 84.4 & 100 \\ \text { Immigrants } & - & 100 & 100 \\ \text { Total Population } & \mathbf{9 0 . 0} & \mathbf{1 0 . 0} & \mathbf{1 0 0}\end{array}$

${ }^{1}$ As per cent of persons born in mainland France; 1999 Census Source: OECD (2001) 
Figure 1: Inflowof foreign population by naionality as a per cent of tot al inflows

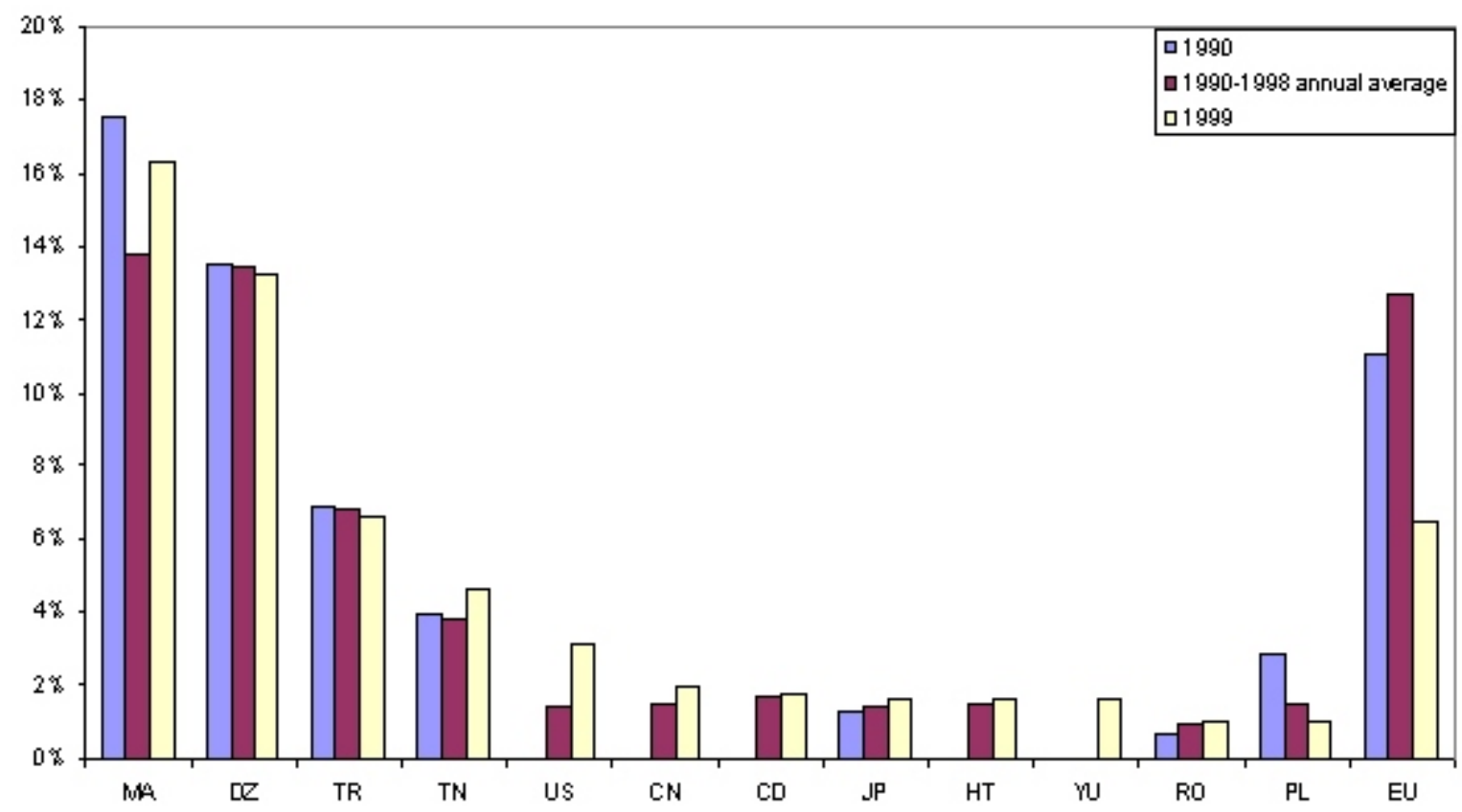

Figme 2 Stock of foreign popuation bynitionatity (in thousands)

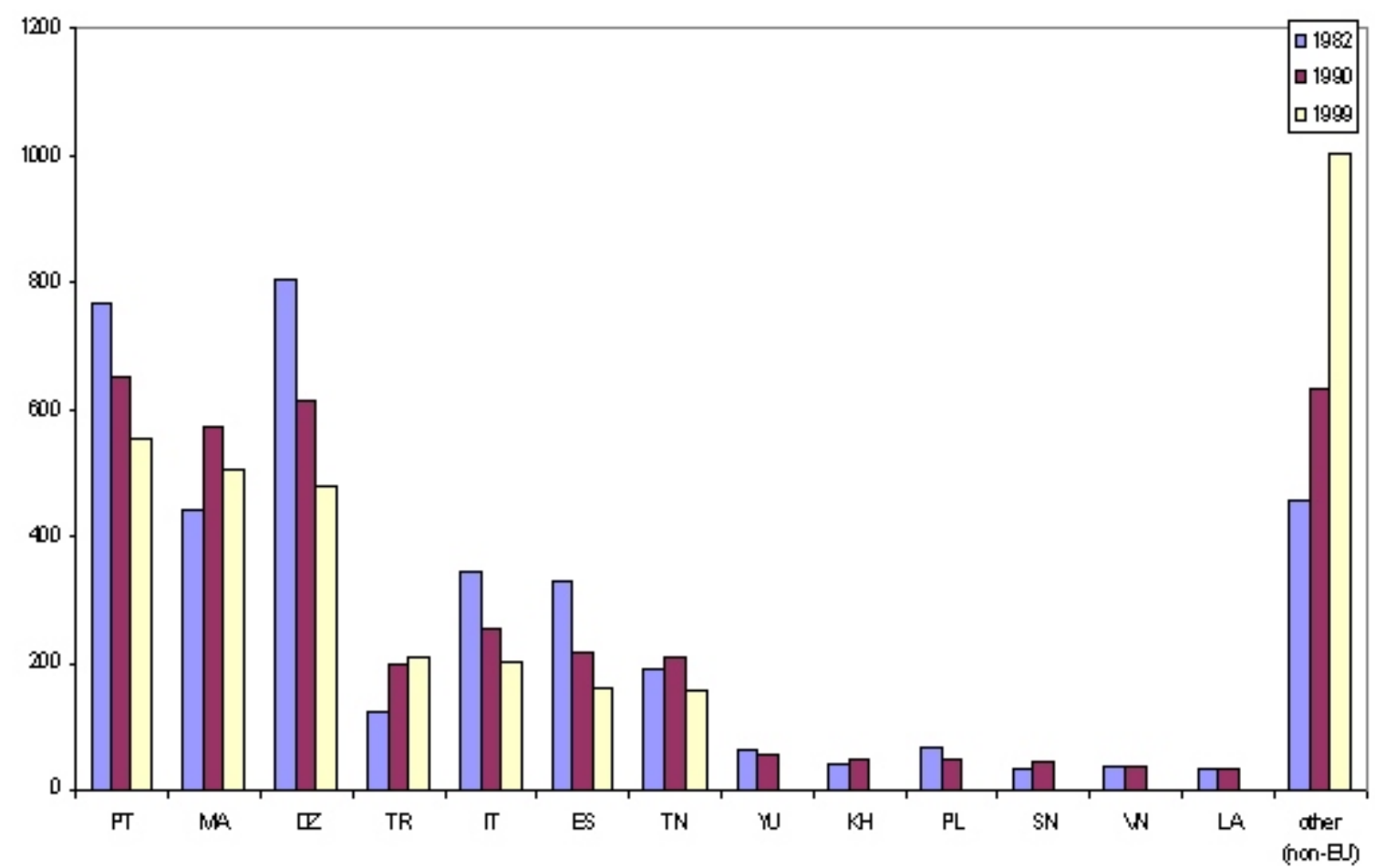




\section{IZA Discussion Papers}

\begin{tabular}{|c|c|c|c|c|}
\hline No. & Author(s) & Title & Area & Date \\
\hline 852 & $\begin{array}{l}\text { A. Kugler } \\
\text { M. Kugler }\end{array}$ & $\begin{array}{l}\text { The Labor Market Effects of Payroll Taxes in a } \\
\text { Middle-Income Country: Evidence from } \\
\text { Colombia }\end{array}$ & 1 & $08 / 03$ \\
\hline 853 & $\begin{array}{l}\text { I. Ekeland } \\
\text { J. J. Heckman } \\
\text { L. Nesheim }\end{array}$ & Identification and Estimation of Hedonic Models & 6 & $08 / 03$ \\
\hline 854 & $\begin{array}{l}\text { A. Ferrer-i-Carbonell } \\
\text { B. M. S. Van Praag }\end{array}$ & Income Satisfaction Inequality and Its Causes & 3 & $08 / 03$ \\
\hline 855 & $\begin{array}{l}\text { B. Irlenbusch } \\
\text { D. Sliwka }\end{array}$ & $\begin{array}{l}\text { Career Concerns in a Simple Experimental } \\
\text { Labour Market }\end{array}$ & 1 & $08 / 03$ \\
\hline 856 & D. Sliwka & $\begin{array}{l}\text { Management Incentives, Signaling Effects and } \\
\text { the Costs of Vertical Integration }\end{array}$ & 1 & $08 / 03$ \\
\hline 857 & $\begin{array}{l}\text { M. Francesconi } \\
\text { A. Muthoo }\end{array}$ & An Economic Model of Child Custody & 3 & $08 / 03$ \\
\hline 858 & C. U. Chiswick & $\begin{array}{l}\text { History of Historical Statistics of the United } \\
\text { States }\end{array}$ & 7 & $08 / 03$ \\
\hline 859 & R. Fahr & $\begin{array}{l}\text { Loafing or Learning? The Demand for Informal } \\
\text { Education }\end{array}$ & 5 & $08 / 03$ \\
\hline 860 & $\begin{array}{l}\text { J. Bonke } \\
\text { N. Datta Gupta } \\
\text { N. Smith }\end{array}$ & $\begin{array}{l}\text { Timing and Flexibility of Housework and Men } \\
\text { and Women's Wages }\end{array}$ & 5 & $08 / 03$ \\
\hline 861 & $\begin{array}{l}\text { Y. L'Horty } \\
\text { C. Rault }\end{array}$ & $\begin{array}{l}\text { Inflation, Minimum Wage and Other Wages: An } \\
\text { Econometric Study on French Macroeconomic } \\
\text { Data }\end{array}$ & 1 & $08 / 03$ \\
\hline 862 & $\begin{array}{l}\text { J. T. Addison } \\
\text { C. R. Belfield }\end{array}$ & Union Voice & 3 & $08 / 03$ \\
\hline 863 & C. U. Chiswick & $\begin{array}{l}\text { Immigrant Religious Adjustment: An Economic } \\
\text { Approach to Jewish Migrations }\end{array}$ & 1 & $08 / 03$ \\
\hline 864 & $\begin{array}{l}\text { D. Cobb-Clark } \\
\text { C. Ryan } \\
\text { R. Breunig }\end{array}$ & $\begin{array}{l}\text { A Couples-Based Approach to the Problem of } \\
\text { Workless Families }\end{array}$ & 6 & $08 / 03$ \\
\hline 865 & S. W. Polachek & $\begin{array}{l}\text { Mincer's Overtaking Point and the Lifecycle } \\
\text { Earnings Distribution }\end{array}$ & 5 & 08/03 \\
\hline 866 & A. Constant & $\begin{array}{l}\text { Immigrant Adjustment in France and Impacts on } \\
\text { the Natives }\end{array}$ & 1 & $08 / 03$ \\
\hline
\end{tabular}

An updated list of IZA Discussion Papers is available on the center's homepage www.iza.org. 